University of Minnesota Morris Digital Well

University of Minnesota Morris Digital Well

2006

\title{
D.H. Lawrence's Women in Love: A Tale of the Modernist Psyche, the Continental "Concept," and the Aesthetic Experience
}

\author{
Michael Lackey \\ University of Minnesota Morris, lacke010@morris.umn.edu
}

Follow this and additional works at: https://digitalcommons.morris.umn.edu/eng_facpubs

Part of the Literature in English, British Isles Commons

\section{Recommended Citation}

Lackey, Michael. 2006. "D.H. Lawrence's Women in Love: A Tale of the Modernist Psyche, the Continental 'Concept', and the Aesthetic Experience," The Journal of Speculative Philosophy 20.4: 266-286.

This Article is brought to you for free and open access by the Faculty and Staff Scholarship at University of Minnesota Morris Digital Well. It has been accepted for inclusion in English Publications by an authorized administrator of University of Minnesota Morris Digital Well. For more information, please contact skulann@morris.umn.edu. 


\title{
D.H. Lawrence's Women in Love: A Tale of the Modernist Psyche, the Continental "Concept," and the Aesthetic Experience
}

\author{
Michael Lackey
}

This is an Accepted Manuscript of an article published by Penn State University Press in The Journal of Speculative Philosophy in 2006, available online: https://muse.jhu.edu/article/216882

Despite the early twentieth century propensity to expose the impossibility of grounding human knowledge, many prominent modernist aestheticians and poets were obsessed with experiencing and/or understanding ultimate reality, an absolute truth that is mind- and cultureindependent as well as universally valid. ${ }^{1}$ For instance, Clive Bell argues in 1914 that "Art is the most universal and the most permanent of all forms of religious expression, because the significance of formal combinations can be appreciated as well by one race and one age as by another, and because that significance is as independent as mathematical truth of human vicissitudes" $(1958,182){ }^{2}$ Following this line of reasoning, aesthetic truth is as objectively and universally valid as the Pythagorean theorem, because, as Roger Fry argues in 1919, an ideal "apprehension" of the aesthetic object is "unconditioned by considerations of space and time" $(1947,23) .{ }^{3}$ Such a reality-based orientation is consistent with T. E. Hulme's aesthetic, which presupposes the artist's ability to overcome "Original Sin" and thereby experience an objective reality that is "purified from anthropomorphism" $(1965,45) .{ }^{4}$ For T. S. Eliot, who claims that "esthetic sensibility must be extended into spiritual perception, and spiritual perception must be extended into esthetic sensibility" (1977a, 103), orthodox Truth exists whether humans apprehend it or not $(1934,32)$, so the artist's primary objective is "to train people to be able to think in Christian categories" (1977a, 22), for Christianity, more than anything else, provides humans with epistemological access to a pre-given orthodox Truth. ${ }^{5}$

At the same time that prominent modernist writers were trying to reconstruct an aesthetic theory that would enable humans to access "essential reality" (C. Bell 1958, 142) or "the nature of reality" (Hulme 1965, 4), two concurrent disciplinary developments were radically undermining this aesthetic project. The first was the split between psychology and philosophy. Toward the end of the nineteenth century, "psychology," which "was much more closely affiliated with philosophy than it is today," "began to emancipate itself as a discipline" (Ryan 1991, 2). Such a split had enormous ramifications, for while philosophy conceived of the human primarily in terms of the mind, an ahistorical and universal thinking faculty that uses logic to ascertain immutable, non-relative Truth, psychology conceived of the human primarily in terms of the psyche, a culturally specific thinking faculty that knows only in relation to its cultural context. Martin Jay intelligently articulates the threat that the emancipation of psychology posed to philosophy: "Reducing the mind to the psyche was problematic for logic and mathematics because it opened the door to relativism in which truth was merely a function of the specific thinking mind in which it appeared or of its cumulative experience over time" $(1996,95)$. In short, psychology's emancipation forced modernists to choose between philosophy's metaphysical mind, which has the capacity to apprehend non-normative and non-relative Truth, or psychology's culturally embedded psyche, which has the capacity to know only in relation to its culture's relative truths. For a prominent modernist like Virginia Woolf, therefore, the choice was clear: "I don't want 'a philosophy' in the least" (1982, 4:126). This was the case because 
modernism, for her, meant choosing psychology: 6 "For the moderns 'that,' the point of interest, lies very likely in the dark places of psychology" $(1984,152){ }^{7}$

The second disciplinary crisis was in philosophy, which led to the analytic/Continental split. ${ }^{8}$ While there are many ways of characterizing this split, I find Richard Rorty's recent formulation insightful and compelling. According to Rorty, analytic philosophers treat the concept like an immutable Idea, an ahistorical precept "which philosophical analysis can hope to pin down" $(2003,21)$. According to this view, there exists a concept that is best suited to represent the world aright and this concept is what it is whether humans perceive it or not. The task of the analytic philosopher, therefore, is to create a system of thinking that would enable humans to access this pre-given, mind-independent concept. In the Continental tradition, by contrast, the concept is treated like a person, "never quite the same twice, always developing, always maturing" (21). ${ }^{9}$ According to this view, concepts are human creations that evolve in relation to the community of language users. Therefore, what the world is in and of itself is simply an incoherent idea. ${ }^{10}$

It was within the context of these two disciplinary crises that D. H. Lawrence penned Women in Love, a novel that brilliantly challenges the aesthetic theories that sought to recover reality. The emergence of the psychological subject that implicitly supplanted the stable, metaphysical mind of philosophy and the transformation of the concept from a stable ontological reality to an evolving semiotic force - these two developments necessitated a new aesthetic, and while many modernists were attempting to rehabilitate the artwork by devising form-based aesthetic theories that were objectively true and universally valid, Lawrence was offering a totally original aesthetic, one that could factor the key developments in psychology and philosophy into the matrix of the aesthetic experience. In the following pages, I will clearly define Lawrence's aesthetic, specifically insofar as it departs from and challenges the dominant aesthetic theories of the early twentieth century.

\section{I.}

In the "Snow" chapter of Women in Love, Lawrence directly addresses the aesthetic debates that were so central to modernism. In this chapter, Ursula and Gudrun Brangwen meet Herr Loerke, a sculptor who espouses an aesthetic theory similar to three of the most prominent aestheticians (Bell, Fry, and Hulme) in Britain in 1916, at the time Lawrence was writing Women in Love. After showing the Brangwen sisters a reproduction of a statuette of a young girl sitting on a horse, Loerke details the aesthetic on which his art object is based: "that horse is a certain form, part of a whole form. It is part of a work of art, a piece of form" $(2000,448)$. The repetition of the word form comically highlights Loerke's pretentious view of his artwork, a modernist view that Lawrence ridicules. ${ }^{11}$ As has been well documented, literary modernism represents a shift from substance to relational models of truth, but as Sanford Schwartz rightly claims, this shift did nothing to challenge the traditional metaphysical assumptions that have dominated western culture from the time of Plato and Aristotle. ${ }^{12}$ Indeed, the "metaphysician's homeland had merely transferred its locale from the transcendent world of Eternal Forms to the immanent surge of the élan vital" $(1985,38)$. In terms of modernist aesthetic theories, the "ultimate reality" that the artwork now embodies or represents is described in terms of formal relations instead of a definable essence. Specifically, "the greatest art," Fry claims, "seems to concern itself with the universal aspects of natural form" $(1947,195)$, a view that he in part found in Bell's theory of 
"significant form"13 : "the peculiarity of the artist would seem to be that he possesses the power of surely and frequently seizing reality (genuinely behind pure form), and the power of expressing his sense of it, in pure form always" (C. Bell 1958, 47). To put this more dogmatically, "the cognitive or representational element in a work of art can be useful as a means to the perception of formal relations and in no other way" (150). "Significant form" (Bell) and/or "natural form" (Fry), therefore, are the ways to ultimate reality for the modernist aesthetician.

When Loerke refers to his artwork as a "piece of form," he is clearly working within the dominant aesthetic tradition in Britain. As Loerke claims, form is not just the basis for modernist aesthetics; it is an ultimate world that exists as a self-contained universe independent of contingent inessentials:

It is a work of art, it is a picture of nothing, of absolutely nothing. It has nothing to do with anything but itself, it has no relation with the everyday world of this and the other, there is no connection between them, absolutely none, they are two different and distinct planes of existence, and to translate one into the other is worse than foolish, it is a darkening of all counsel, a making confusion everywhere. Do you see, you must not confuse the relative world of action, with the absolute world of art. $(2000,449)$

There are three separate points in this passage that bring to mind the aesthetic theories of Bell, Fry, and Hulme. First, the true work of art is a hypostatic embodiment of the absolute. For Bell, it matters little how you refer to "the absolute world of art," so long as you recognize its ultimate character: "Call it by what name you will, the thing that I am talking about is that which lies behind the appearance of all things - that which gives to all things their individual significance, the thing in itself, the ultimate reality" $(1958,54)$. This "world of art" is superior to quotidian existence because it has, as Fry claims, "a quality of permanence and reality that does not belong to the rest of our experience" $(1947,36)$. In other words, there is something whole and complete in the world of art that is absent from the everyday world.

Second, for this theory of an "absolute world of art" to function, there must be a strict division between two planes of existence, what Loerke terms "the relative world of action" and "the absolute world of art" $(2000,449)$. Everyday life is governed by practical and relative matters, that which is a mere means to an end, while the absolute world of art transcends contingent inessentials. Consequently, when a person has a true aesthetic experience, there is, as Fry argues, "no reference to actual life," for "our apprehension is unconditioned by considerations of space and time" $(1947,33)$. To put this in Bell's words: "Art transports us from the world of man's activity to a world of aesthetic exaltation. For a moment we are shut off from human interests; our anticipations and memories are arrested; we are lifted above the stream of life" $(1958,27)$. Given this spiritual character of the artwork, Bell likens art and religion, for both "belong to the same world. .. . The kingdom of neither is of this world" (63).

Finally, and most important, placing the aesthetic object in a world that transcends the inessentials of quotidian life presupposes within the human a universal reality or faculty that exists independent of material, psychological, and cultural contingencies. For modernist aestheticians, the true artwork cannot be treated as an anthropomorphic construction. On the contrary, true art is "non-human," something that is "absolutely distinct from the messiness, the confusion, and the accidental details of existing things" (Hulme 1965, 87). Given the clear 
division between the non-human and the human, the absolute purity of the world of art and the contingent messiness of the quotidian world, Loerke, like Hulme, claims that "to translate" one distinct plane of existence into another "is worse than foolish; it is a darkening of all counsel, a making confusion everywhere" (2000, 449).

The artwork's status as an ahistorical object corresponds to the human's ability to transcend its condition as a culture-, space-, and time-bound being, and it is this yearning for and belief in the existence of a non-contingent universal reality or faculty within the human that led many modernists to develop a reality-based aesthetic theory. Central to Bell's aesthetic is a clear distinction between two types of emotion. The first, the "emotions of life" $(1958,28)$, relates to the material world, the mundane concerns of practical living. For Bell, "to use art as a means to the emotions of life is to use a telescope for reading the news" (29). What concerns Bell is the "transcendent emotion" (181) in which art "expresses some profound and general emotion common, or at least possible, to all ages, and peculiar to none" (159). This emotion is not governed by the contingencies of culture, time, or space, for those who have this aesthetic experience "feel that their religious, aesthetic, or moral emotions are not conditioned, directly or indirectly, by physical needs, nor, indeed, by anything in the physical universe. Some things, they feel, are good, not because they are means to physical well-being, but because they are good in themselves" (67). Religious, aesthetic, and moral emotions transcend the human's spatial and temporal condition; they are universal experiences that are neither determined nor conditioned by a subject's biological or psychological embeddedness in the world.

Hulme, who rejects the projectionist psychologies that are distinctive to writers like Ludwig Feuerbach, Nietzsche, and Freud, sketches the consequences of a psychological orientation toward knowledge in order to expose its dangers and flaws. The current danger, Hulme argues, is the rejection of philosophy and science as objective disciplines. In other words, psychology, which would reduce all truth systems to a Weltanschauung, is a threat to the universal and objective Truths of science and philosophy. What Hulme is ultimately rejecting is Nietzsche's claim that truth is an anthropomorphic construction. For Nietzsche, were there no humans to create sentences, there would be no "truths," for "truth claims" are not objective facts dangling from a pre-given heaven of Ideas; they are human and culturally constructed illusions, that is, productions of an individual and/or communal psyche. Hulme unambiguously rejects this view. He wishes to purge philosophy of "anthropomorphism" so that he could reestablish an "objective basis" for knowledge, a basis that does "not in the least depend on the human mind" $(1965,45)$. Once philosophy has purged itself of the anthropomorphic and empirical prejudice, "it becomes possible to think of certain 'higher' concepts, those of the good, of love, etc., as, at the same time, simple, and not necessarily to be analysed into more elementary (generally sensual) elements" (45).

This distinction between the contingent world of anthropomorphism (psychology) and the objective world of philosophy corresponds to Hulme's distinction between romantic and classicist aesthetics. For the romantics, whose aesthetic ultimately destroys wonder (140), the human is defined in terms of an evolving, dynamic flux, forever progressing and "full of possibilities" (117). For the classicist, by contrast, the human is a being with a "fixed nature," and this nature "should be as fixed and true for every man as belief in the existence of matter and in the objective world" (118). The question for Hulme, who endorses the classicist aesthetic, is 
how to access this nature. The answer cannot lie in the intellect, which analyzes, because it stands baffled before synthesis (139), a necessary act for aesthetic appreciation. In other words, given the intellect's limitations, it cannot represent or comprehend art. Therefore, to truly appreciate the artwork, a person must make use of a more visceral faculty, what Hulme and Henri Bergson refer to as intuition. For Hulme, intuition is an immediate, holistic apprehension of reality, something that only a true (classicist) art object would yield and something that is only accessible to a being (the metaphysical mind) that can transcend the contingencies of the empirical and the anthropomorphic.

For the sake of clarity, let me briefly summarize the key ways in which Loerke's aesthetic resembles the theories of Bell, Fry, and Hulme. Bell, Fry, and Loerke make form the basis of their aesthetic. More importantly, for all four, the true artwork, like analytic philosophy's immutable concept, exists in a world that is not conditioned by cultural, temporal, or spatial contingencies. Indeed, art's significance "is as independent as mathematical truth of human vicissitudes" (C. Bell 1958, 182), which explains why humans can obtain knowledge that does "not in the least depend on the human mind" (Hulme 1965, 45). Consequently, should the artwork be tainted by the temporally, spatially, or culturally conditioned psyche, it would cease to be an artwork. So for Loerke, Bell, Fry, and Hulme, who are more indebted to traditional philosophy than modernist psychology, purging the human and the artwork of the contingent and the relative is an intellectual must for the aesthetic experience to occur.

\section{II.}

Ursula, who has adopted a Nietzschean philosophy, rejects Loerke's distinctly modernist form-based aesthetic. Before turning to her critique of Loerke, however, let me briefly clarify the way in which Nietzsche influenced Lawrence's writings. Nietzsche was one of the most prominent influences on Lawrence's thinking. Indeed, Nietzsche's influence on Lawrence is not just based on scholarly inference, for in D. H. Lawrence: A Personal Record, Jessie Chambers, Lawrence's childhood intellectual confidante and one of his early lovers, claims that he began reading the Übermensch philologist's writings in 1908, just after he started teaching in Croydon $(1965,120)$. But how much influence Nietzsche had on Lawrence and specifically what works Lawrence read are still matters of speculation. Nonetheless, for scholars like Harry Steinhauer (1949), Colin Milton (1987), Daniel J. Schneider (1986), Michael Ragussis (1978), Michael Bell (1992; 1997; 2001), and Robert E. Montgomery (1994), Nietzsche's presence in Lawrence's work is extensive, so much so that Steinhauer claims that Lawrence "takes over the Nietzschean 'system' in its entirety" (1949, 225), while Milton concludes that "the German philosopher did indeed profoundly affect Lawrence's whole vision and with it, the character of the fictional world he created" $(1987,232)$.

More specifically, scholars consistently claim that in appropriating Nietzsche, Lawrence also accepts the philosophy of Arthur Schopenhauer, for, as Michael Bell claims, "Lawrence, like Nietzsche, had absorbed" Schopenhauer "metaphysically" (1992, 109). Bell is not alone in thinking this way. When discussing the Lawrencian will, Schneider claims: "Following Schopenhauer, Nietzsche argued that man is motivated, not by spirit or mind . . ., but by the deep instinctive will - which is not just a will to live but also a will to power" $(1986,58)$. Later, this Schopenhauerian/Nietzschean interpretation is the basis for Schneider's reading of Lawrence: "Beneath the ego lie the deepest desires of the soul, the self as a manifestation of the 
greater inhuman will that sweeps men and women together-and then apart" (80). Milton uses a similar approach: "Since he regards the Will as the ground of all being, Schopenhauer-again like Nietzsche and Lawrence-holds that intellect and consciousness are essentially instruments of instinct rather than independent faculties" (1987, 7-8). Kingsley Widmer makes the same interpretive move by claiming that the Schopenhauer/Nietzsche will significantly influenced Lawrence's view: "While it is usual to see Schopenhauer (also read by Lawrence) behind Nietzsche's view of Will, . . there may be other heritages to these essential Nietzsche-Lawrence tropes" $(1985,149)$. All of these critics trace the Lawrencian will primarily back to Schopenhauer and Nietzsche and they believe that the two German writers conceive of the will in the same manner.

But Schopenhauer and Nietzsche have radically different notions of the will. Schopenhauer claims that the "World as representation" is "something secondary," while what "is primary" is "the thing-in-itself, which we shall afterwards learn to recognize as the will" (1969, 2:16). Milton intelligently summarizes the Schopenhauerian will thus: "Will is both more fundamental and more pervasive than 'will' in the ordinary sense; a metaphysical rather than a psychological entity, Will is the ground of all being" $(1987,6)$. Nietzsche, however, claims that the will is a psychosemiotic construction, a psychological projection that assumes a provisional form in and through a semiotic sign. Indeed, in Twilight of the Idols, he insists that the traditional 'knowing' faculties are semiotically and psychologically projected into the 'human': "The 'inner world' is full of phantoms and false lights: the will is one of them" $(1989 \mathrm{a}, 59)$. He continues:

Man projected his three "inner facts," that in which he believed more firmly than in anything else, will, spirit, ego, outside himself - he derived the concept "being" only from the concept "ego," he posited "things" as possessing being according to his own image, according to his concept of the ego as cause. No wonder he later always discovered in things only that which he had put into them! (59$60)$

Given that "inner facts" are psychosemiotic constructions, it is not surprising that Nietzsche rejects the existence of the will as an ontological reality: "there is no such thing as will" (1960, 270). This is a point that he makes a number of times: "There exists neither 'spirit,' nor reason, nor thinking, nor consciousness, nor soul, nor will, nor truth" (1960, 266); "At the beginning stands the great fateful error that the will is something which produces an effect - that will is a faculty. . . . Today we know it is merely a word" (1989a, 48); "the doctrine of the will has been invented essentially for the purpose of punishment, that is of finding guilty" (63). On the basis of this distinction between an ontological and a constructed will, I want to challenge the standard interpretation of the Schopenhauer/Nietzsche will by suggesting that Lawrence was more clearly in the tradition of Nietzsche than Schopenhauer. Once I do this, I will then detail Lawrence's post-metaphysical and post-reality aesthetic.

As an artist who has access to reality as such, Loerke insists that his painting is pure form, in no way tainted by fleshly desire. But Ursula rejects this assertion; she claims instead that art objects represent, not a pure metaphysical or transcendental form, but the creative impulse and desire of the artist:

What do you mean by a horse? You mean an idea you have in your head, and which you want to see represented. This is another idea altogether, quite another idea. Call it a horse if you like, or say it is 
not a horse. I have just as much right to say that your horse isn't a horse, that it is a falsity of your own make-up. $(2000,449)$

For Ursula, because Loerke is all-too-human, his representation of the horse can never be an ideal form or a self-contained aesthetic form, and this is the case for two reasons. First, to believe that the absolute work of art embodies an ideal form is to presuppose that an ideal form exists. Loerke is clearly working within a Platonist aesthetic tradition at this point. In the Ion, when discussing the type of Knowledge that poets and seers possess, Socrates defines it as a mindindependent reality uncorrupted by the human. In a moment of inspiration, "the deity" divests the inspired ones of their senses. The deity does this so "that we listeners may know that it is not they who utter these precious revelations while their mind is not within them, but that it is the god himself who speaks, and through them becomes articulate to us" (Plato 1961, 220). Notice how Socrates underscores the fact that it is not humans "who utter these precious revelations." The implication is that, were humans to participate in the utterance of the "precious revelations," the "knowledge" that they would express would be tainted by the subjective element, thus rendering it historical and/or cultural. But because "these revelations" are not tainted by a human agenda ("not of man or human workmanship"), we can conclude that they are "divine and from the gods," which is to say that the "precious revelations" would qualify as authentic Knowledge. As a true artist, Loerke knows that an Ideal Form exists, and given his privileged epistemological station as an artist, he believes that he can overcome his cultural embeddedness and thereby know and represent this Form.

Second, even if a world of ideal forms exists, Ursula would insist that our representations of that world would always be heavily inflected by our human desire. For this reason, to distinguish the ideal world of art from the everyday world is to establish a false dichotomy, one that cannot be maintained once knowledge is placed at the mercy of the will. Ursula's comments anger Loerke, so he restates his position, this time distinguishing more clearly "the relative world of action" from "the absolute world of art." The two worlds are as separate as they are distinct, and the artist is strategically positioned to transcend the relative world of action and thereby represent, through the art object, the absolute world, what is commonly referred to as reality. But if the desires of the will determine the dictates of reason, then reason's constructs would be the product of a human's everyday needs, and not a mind-independent reality. In an alternately Schopenhauerian and Nietzschean moment, Ursula intelligently critiques Loerke's aesthetic:

"As for your world of art and your world of reality," she replied; "you have to separate the two, because you can't bear to know what you are. You can't bear to realise what a stock, stiff, hidebound brutality you are really, so you say 'it's the world of art.' The world of art is only the truth about the real world, that's all—but you are too far gone to see it." $(2000,450)$

Ursula's "hide-bound brutality" is in part Schopenhauer's will. For Schopenhauer, the will is a primal, brutal force, a pre-moral life-urge subject to no rational laws. Indeed, the mind, instead of ruling the will, is just an instrument of the will, a tool that the will will use to satisfy its thirst for life and power. When Ursula criticizes Loerke, she is faulting him for constructing an aesthetic that naively and falsely denies the existence and/or influence of the primal life force, what early Lawrence refers to as "blood-consciousness" (1982, 2:470), on our knowing faculty. Therefore, Loerke's "world of art" is actually a direct product of his "hide-bound brutality," whether he realizes it or not, and his attempt to distinguish two separate planes of existence is nonsense. 


\section{III.}

But what is the "nature" of this "hide-bound brutality" and how are we to define it? The answer to this question lies in Lawrence's strategic references to the Nietzschean concept of the will. It is important to note that Nietzsche distinguishes two types of wills: the metaphysical Will, which Nietzsche refers to as a "closed system of will" $(1989 \mathrm{~b}, 146)$, and the metaphorical "will," which is his psychosemiotic creation. Lawrence makes the same distinction. For instance, Birkin's early love interest, Hermione, who is always "struggling to gain control with her will" $(2000,103)$, is governed by the "bullying will" (37), "an almost insane will" (86), and an "all-powerful will" (89). This same will controls Gerald, for he believes that "Man's will was the absolute, the only absolute" (230), an idea that is the basis for the way he manages his business: "this was the sole idea, to turn upon the inanimate matter of the underground, and reduce it to his will" (234).

For Lawrence, the Western tradition has been predicated on this absolute and destructive will to power, one in which women, for instance, are forced into a degrading role of submission to the male through the traditional institution of love. Such a situation can only have dire consequences on human relationships as Lawrence illustrates through Gerald's parents. Adhering to a traditional view of love ("The old way of love seemed a dreadful bondage, a sort of conscription" [204]), Mr. and Mrs. Crich establish "a relation of utter interdestruction" (224). This is the case because Mr. Crich imposes an all-powerful will on his wife, but his wife is also guilty because she submits to that will, accepting it as final and absolute: "as time went on, she never opposed her husband in word or deed. . . . she submitted to him, let him take what he wanted and do as he wanted with her" (224). Gerald and Gudrun re-enact the Crich relationship by setting into motion an absolute will-to-power dynamic. So perverse and absolute is Gerald's will that he "would destroy" Gudrun "rather than be denied" (419), and for a short period, Gudrun responds to Gerald just as Mrs. Crich did to Mr. Crich: "She lay looking at him as at something she could never understand, never: as a child looks at a grown-up person, without hope of understanding, only submitting" (420). In relation to Gerald's absolute will-to-power, Gudrun has one of two choices: total submission or a destructive assertion of her own absolute will-to-power. Later in the novel, she opts for the latter. After living under Gerald's tyrannical patriarchal will, she decides to respond to him with as much vehemence: "It was her overbearing will that insisted" (462). Not surprisingly, Gerald and Gudrun's relationship is one "of utter interdestruction," a replica of the Crich relationship.

Loerke is a character who wields this absolute will-to-power over others, but he does so in a much subtler way. For instance, after realizing the destructive nature of her relationship with Gerald, Gudrun abandons him in favor of Loerke. When Gudrun first meets Loerke, he is with his "young love-companion," Leitner, a younger man who is a penniless dependent (429). Like Gerald, Loerke exerts an absolute will-to-power over his partner and Leitner resents it: "His partner, too, the big, fair, good-looking youth, was ill at ease, going about as if he belonged to nowhere, and was kept in some sort of subjection, against which he was rebelling" (439-40). As a wielder of an absolute will, Loerke is described as "a pure, unconnected will, stoical and momentaneous" (445). But what distinguishes him from Gerald is his ability to wield this will without being exposed: "Loerke knew a secret beyond these things. The greatest power is the one that is subtle and adjusts itself, not the one which blindly attacks" (470). Because Gudrun effectively exposes Gerald's overt will-to-power, she can reject it, but Loerke, by subtly adjusting himself in relation to Gudrun, can assert the same will without detection. When Ursula 
refers to Loerke's "hide-bound brutality," she is accusing him of wielding an absolute will to power, one that, as Nietzsche claims, sets itself up as the one way, the single truth, and the only life. As such, this "closed system of will, goal and interpretation" (Nietzsche 1989b, 146) blocks out any possibility for alternative perspectives.

Birkin also adopts a will-to-power mentality, but his differs considerably from Hermione's, Loerke's, and Gerald's. In a conversation with Gerald about education, Birkin tells his friend: "Instead of chopping yourself down to fit the world, chop the world down to fit yourself" $(2000,211)$. On the basis of this comment, it would seem that Gerald does exactly what Birkin suggests, for Gerald, in his business, subjects the world to his will-to-power: "There were two opposites, his will and the resistant Matter of the earth. And between these two he could establish the very expression of his will, the incarnation of his power" (234). But whereas Gerald adopts an absolute will-to-power that admits of no opposition, the "closed system of will," Birkin develops a metaphorical 'will'-to-power, one that can only be created with the assistance of another, but also one that leaves open the possibility for its own deconstruction. Birkin, in fact, refers directly to the Nietzschean concept, but he reworks it into "a volonte de pouvoir, if you like, a will to ability, taking pouvoir as a verb" (152). Notice how Birkin renames the Nietzschean Wille zur Macht: translating it into French, converting the noun into a verb, and shifting the focus from power to ability. Nietzsche would be delighted. ${ }^{14}$ Instead of treating the Will as a metaphysical entity, as Schopenhauer does, Birkin treats it as a provisional concept, an idea that is subject to a deconstruction and a subsequent reconstruction, a never-ending process of conceptual evolution. Indeed, Birkin even leaves open the possibility of deconstructing his own "volonte de pouvoir" by telling Ursula to call it that "if you like." Were Birkin to endorse an absolute volonte de pouvoir, one that leaves open no possibility for its own deconstruction, he would be acting as if his concept were an ultimate reality, an absolute truth - in other words, he would be acting like Schopenhauer, who treats the Will as the metaphysical argument of life and the world. But since Birkin rejects the belief in a pre-existent ontological Reality, he treats his volonte de pouvoir as a provisional construct. In essence, we could say that Gerald is Schopenhauerian (and not Nietzschean) because he accepts the Wille zur Macht as a metaphysical fact of Being, whereas Birkin is - paradoxically-Nietzschean (and not Schopenhauerian) because he rejects Nietzsche's Wille zur Macht and creates his own "reality," that provisional concept known as the volonte de pouvoir.

Given Birkin's view of the metaphorical volonte de pouvoir, his own psychosemiotic construction that he invites Ursula to deconstruct, he has a much healthier relationship with his partner than Gerald, Hermione, or Loerke could ever have with anyone. Indeed, Birkin and Ursula experience what Nietzsche refers to as "star friendship" (1990, 226). Significantly, like Nietzsche, Birkin claims that "star friendship" is a prerequisite for effective use of his volonte de pouvoir. That Lawrence specifically has Nietzsche's concept of friendship in mind is clear from his frequent references to stars whenever the topic of friendship arises. For instance, in the Mino chapter, Birkin says to Ursula: "'What I want is a strange conjunction with you. . . . an equilibrium, a pure balance of two single beings:- as the stars balance each other'" $(2000,149)$. What Birkin means is "'two single equal stars balanced in conjunction-'" (153), a relationship that is not selfless, but the fulfillment of both selves: "'it is a maintaining of the self in mystic balance and integrity - like a star balanced with another star"' (154). When such a balancing of wills does occur, as it does for Birkin and Ursula, it is referred to as "star-equilibrium" (333), 
whereas for Gudrun and Gerald, when their relationship is nearing its fatalistic end, it appears that "large white stars were flashing out" (466).

\section{IV.}

At this point, let me begin defining Lawrence's aesthetic. For Lawrence, the art object cannot signify, represent, or embody "essential reality" or "the nature of reality" because there is no such thing as reality. There is only what he refers to in his essay "Democracy" as "indefinable presence" (1988a, 78), an adiscursive "entity" that neither invites nor resists signifying systems. In other words, indefinable presence can never be reduced to an idea, since it is prior to conceptual categories like substance, truth, reality, and form. For Lawrence, once humans embrace modern psychology's contingent psyche and Continental philosophy's evolving concept, the aesthetic objective would no longer be an apprehension of a metaphysical reality (analytic philosophy's immutable concept, which is accessible only to traditional philosophy's metaphysical mind). Rather, it would be the endless re-creation of everyday life and the human psyche. Ursula gestures toward this aesthetic when she faults Loerke for pretending to represent the horse through his art. What Loerke fails to realize is that his aesthetic representation is merely "an accidental cohesion in the flux of time" (Lawrence 1988b, 272), a production of his own will to power ("hide-bound brutality") over indefinable presence, but for Ursula, all art objects, instead of representing "a certain [metaphysical] form," reflect the will and desire of the artist - "'I know it is a picture of himself, really"' $(2000,449)$. To understand what Ursula's claim implies, let us briefly analyze Loerke's world of art in relation to Lawrence's indefinable presence. According to modernist aestheticians like Loerke, the true artwork embodies a mindand culture-independent Reality, a "significant form" that appeals to a "transcendent emotion." In short, the modernist artwork bodies forth a metaphysical reality because it is "unconditioned by considerations of space and time." For Ursula, however, a construction of the ego, whether an art object or a specific discourse, is the production of an individual's or a culture's desire and power; it is a psychosemiotic projection, which assumes a provisional form in and through a semiotic sign, imposed upon indefinable presence. Therefore, the art object can only be a human- and culture-conditioned creation. As Ursula says to and of Loerke: "it is a falsity of your own makeup"; "I know it is a picture of himself"; and "The horse is a picture of your own stock stupid brutality."

As should be obvious, Ursula's thinking is stunningly similar to Nietzsche's. The artist creates an innocent lie to represent "indefinable presence." For the traditional artist, however, who has a propensity to convert his innocent lie into an absolute truth, he will use the assertive will-to-power (what Nietzsche refers to as the closed system of will) to persuade the masses that his creation is metaphysically binding. Here is how Lawrence describes the reification process in his "Crown" essay. Having persuaded "the crowd of assertive egos," these masses can extinguish all alternative representations, which leaves "the fixed will of the temporal form we have so far attained, the static, mid-way form" to triumph "in assertion" (1988b, 277). Once this will to power gains cultural legitimacy, people forget that the representation has a human origin, that it is an individual's will to power pawning itself off as an absolute truth: "the human ego, in its pettifogging arrogance, sets up these things for you as absolutes, and unless you kick hard and kick in time, they are prison-walls for ever" (287). By exposing Loerke's "absolute world of art" as the product of his "hide-bound brutality," Ursula is kicking hard and maybe in time. But for Loerke (and aestheticians like Bell, Fry, and Hulme), who has been disconnected from the all- 
too-human source of meaning, the artwork effectively masks its originary basis in desire and power and is therefore considered objectively true. This explains Ursula's comment to Loerke"you are too far gone to see it." Having denied his sensual existence and lived in the "absolute world of art," Loerke has become a victim of his own creation; he has deluded himself into thinking that it is a mind-independent Reality, a metaphysical argument about life and the world, which has made him incapable of seeing his artistic creation as a product of his own desire for power.

The consequence of the assertive-will aesthetic is a psychological submission that leads to the death of the creative and autonomous self. For both Mrs. Crich and Gudrun, being in a relationship with someone who wields an assertive will leads to a fatalistic submission. Mrs. Crich "submitted to" her husband and let him "do as he wanted with her" (2000, 224), while Gudrun looked at Gerald "as a child looks at a grown-up person, without hope of understanding, only submitting" (420). This is exactly the kind of response that Loerke expects from his audience. Notice how Loerke responds when Ursula challenges his claim that his Kunstwerk is not a representation of the horse, but a "picture of himself": "Loerke snorted with rage." Loerke's condescending dismissal reflects his own refusal to brook dissent. Instead of using his artwork to initiate a dialogue or to establish "star-equilibrium" between the artist and audience, Loerke tries to shut Ursula down. As an artist who wields a closed system of will, he wants Ursula to respond to him just as Mrs. Crich and Gudrun respond to Mr. Crich and Gerald.

If the traditional artwork cows a person into submission, Lawrence's artwork inspires a person to create a new world. It is in and through Birkin's "star-equilibrium," which is a version of Nietzsche's "star friendship," that Lawrence dramatizes the ideal relationship between the artist and his/her audience. Notice, for instance, that when Ursula begins her relationship with Birkin, she becomes an entirely new being. But it is important to note that this being cannot be defined: "Her soul was new, undefined and glimmering with the unseen" (385). What makes Ursula's transformation here so radical is her indefinability. By becoming "undefined and glimmering with the unseen," she learns to live in perpetual distance from ready-made discourses about the human. This is the same view of Birkin, who realizes that there can be no definitive statement about the "self," because all conceptual systems ultimately destroy indefinable presence: "How could he say 'I,' when he was something new and unknown, not himself at all? This I, this old formula of the ego, was a dead letter" (386). The moment indefinable presence is reduced to the dictates of language ("dead letter"), that is, once it is reified into an immutable concept, it can no longer become what has yet to be imagined. In Lawrence's world, the first function of the art object is to liberate humans from the tyranny of the immutable concept and the metaphysical mind so that humans can understand and experience life, the human, and the world as indefinable presence.

To get a fuller sense of this aesthetic, let me repeat one of Birkin's comments to Gerald, but this time quoting an additional sentence: "Instead of chopping yourself down to fit the world, chop the world down to fit yourself.-As a matter of fact, two exceptional people make another world" (211). Notice how Lawrence uses a dash to establish an essential connection between his advice to Gerald about the world and the need to engage the world with another person. For Lawrence, to chop the world down to yourself in a healthy manner, one must understand that there can be no final or absolute chopping down - the world is indefinable presence, so using an 
absolute will to chop the world down would only destroy the world. When "two exceptional people" come together, they will oppose each other by imposing their own volontes de pouvoir upon each other, but they will never demand or insist that the other accept their imposition as final or absolute: "I want you to drop your assertive will" (259), Birkin tells Ursula. This does not mean that Birkin does not want her to impose $a$ will on him. Rather, it just means that he does not want her to impose an absolute will on him, the "assertive will": "'While ever either of us insists to the other, we are all wrong" (260). ${ }^{15}$ This experience of the will significantly differs from Gudrun's: "It was her [Gudrun's] overbearing will that insisted" (462). For Birkin's exceptional people to grow and develop, there must be an imposition of the will, but it must be provisional, open to a potential deconstruction and a subsequent reconstruction, a process that benefits both parties. For instance, in the Excurse chapter, when Ursula berates Birkin for indulging himself in Hermione's "obscene and perverse" "spiritual intimacy," Birkin initially fights back and defends his own position. But after he has some time to reflect on her comments, he "gave up his old position" and claims: "No doubt Ursula was right" (321). For someone like Loerke, because his artwork represents the object in itself, there is no possibility of getting him to revise his view of the world or to create beyond his "dead letter" creation. But for Lawrence, the only way two people can grow is to endlessly question and challenge each other's positions; they must expose the debilitating and destructive assumptions built into their philosophies as the two construct new worlds, new realities, and new truths: "If only he could call a world into being, that should be their own world!" (408), Birkin says. Once the star-friendship dynamic is set into motion, two exceptional people can "make another world" out of indefinable presence, as long as the two recognize of course that such a new world is only a provisional construct.

To conclude this essay, I want to underscore the differences between the aesthetics of metaphysical modernists (like Bell, Fry, Hulme, and Loerke) and psychosemiotic modernists (like Nietzsche, Lawrence, Birkin, and Ursula), and to do this, I imagine how Loerke would have conceived of the volonte de pouvoir were he the originator of this concept and how Birkin would have responded to Ursula were he the creator of Loerke's statuette of the horse. For Loerke, who wields an absolute Wille zur Macht over indefinable presence and others, there exists a reality that is what it is whether humans perceive it or not, and for those epistemologically privileged humans who have access to this "essential reality," they are best stationed to represent it as it is in and of itself. In other words, like Plato's seer from the Ion, Loerke's representation of a concept like the "volonte de pouvoir" would be a precious revelation from the heavens, "not of man or human workmanship." Not coincidentally, Ursula brings up the idea of the Wille zur Macht when discussing "Gerald Crich with his horse." As a train passes by and terrifies Gerald's horse, he whips the poor beast into submission. Ursula refers to Gerald's behavior as "a lust for bullying - a real Wille zur Macht." Like Loerke, Gerald coerces a horse into submission to his "assertive will," his "closed system of will." After Ursula and Birkin refer to Gerald's Wille zur Macht as "a base and petty thing," Birkin offers a tenuous defense of the concept by redefining it: "It is a volonte de pouvoir, if you like, a will to ability, taking pouvoir as a verb" (152). Were Loerke the person defining or redefining the concept, here is how his sentence would read: "It is a volonte de pouvoir, a will to ability, taking pouvoir as a verb."

As a metaphysical modernist, Loerke would not interject the phrase, "if you like," and this is the case for three reasons. First, the phrase, "if you like," is more suited to Lawrence's view of life and the world as "indefinable presence." Humans can construct a variety of 
discourses to represent the world, so they suggest that we could think of the human in terms of "a volonte de pouvoir," but there is nothing that compels us to do so. In other words, Lawrence and Birkin, following Nietzsche, recognize that the world is not some sacred hieroglyph waiting to be decoded. Rather, as Nietzsche claims: "We have arranged for ourselves a world in which we can live-by positing bodies, lines, planes, causes and effects, motion and rest, form and content; without these articles of faith nobody now could endure life. But that does not prove them. Life is no argument" $(1990,177)$. For those who believe that life and the world, as argument, are waiting to be rightly signified and represented in and through language, there is a right concept that maps logically and naturally onto the world, and once a person has discovered this pre-given concept, the philosophical and aesthetic task is to pin it down as precisely and accurately as possible. Failure to discover or understand this pre-given concept would lead to a distorted or inaccurate conceptual picture of the world. For Nietzsche and Lawrence, by contrast, life and the world are mind-independent, but there are no mind-independent concepts that are best suited to signify the world aright. This does not mean that Nietzsche or Lawrence considers concepts useless or unnecessary-Nietzsche says that we could not endure life without them. It just means, as it does for those in the Continental tradition, that the concept is a human construction, and as such, it will shift and evolve in relation to the various communities of language users. Given this view, to think that the world has an essential nature would be a failure to understand that life and the world are no arguments. Or, to put this in the words of Lawrence, it would be a failure to understand that life and the world are "indefinable presence $[\mathrm{s}]$," adiscursive entities that are indifferent to language, concepts and truth. For Loerke, by contrast, the human and the world are conceptually what they are whether humans know it or not, and since he thinks of himself as best epistemologically stationed to know a thing in itself, he talks as if there were an ontological necessity to what he says. Loerke, therefore, would not say, "if you like," because to do so would be a tacit admission that our concepts of things could be other than what they are.

Second, the "if you like" admission would suggest that his creation is a humanconstructed concept rather than an immutable, pre-given reality. Were Ursula to tell Loerke that his idea of the "volonte de pouvoir" were "a picture of himself, really," Loerke would respond with indignation ("Loerke snorted with rage"), because he, like Hulme, believes that we can access a truth that does "not in the least depend on the human mind." Therefore, Loerke's representation of objects would "be as fixed and true for every man as belief in the existence of matter and in the objective world" (Hulme) So instead of tacitly acknowledging that his subjective position in the world would have contributed to the construction of his "volonte de pouvoir," he would utilize a discourse that conceals or even denies the role the human subjective plays in the construction of the concept.

Finally, by saying "if you like," Birkin tacitly invites Ursula to accept, reject, or redefine his concept. Instead of thinking of the concept as stable without fluctuation, he considers it a mere instrument to expand the self and other. As such, Birkin wants to work with Ursula in the construction of a new world and new selves. For Birkin, "You've got to learn not-to-be, before you can come into being" $(2000,39)$. Because "humans" are brought into being as "subjects" through the culture's ready-made formulas, there is the real danger that people will consider the formula a person's "true Self." In a conversation with Gerald, Birkin claims that the human is "just one expression of the incomprehensible" - in this case, the incomprehensible means that which cannot be defined, that which cannot be signified through language ("Her soul was new, 
undefined and glimmering with the unseen."). And herein lies the problem, according to Birkin: "Humanity doesn't embody the utterance of the incomprehensible any more. Humanity is a dead letter" (55). The moment the 'human' as an "expression of the incomprehensible" is subjected to the dictates of a signifying system, it is a "dead letter," a Bartlebyesque cadaver. This is Loerke's view of the human. Loerke would eliminate the phrase, "if you like," because it is impossible for others to engage in the process of constructing what already exists and is. His task, therefore, is to represent what is, not to invite others to work together in the construction of a new world or a new human.

Were Birkin the creator of Loerke's statuette, he would respond very differently to Ursula's critique, and it is important to note that Ursula does not object to Loerke's aesthetic creation; she objects to his denial that his subjective interests and desires have played a role in his aesthetic creation. Were Ursula to tell Birkin that his horse is a falsity of his own make-up, that it is his own "accidental cohesion in the flux of time" imposed upon indefinable presence, Birkin would agree. But more than that, Birkin would invite Ursula to work with him and to use the aesthetic object so that the two "could call a [new] world into being." The art object is not an end in itself that gives humans access to a pre-given reality; rather, it is a self-acknowledged construction imposed upon indefinable presence, which is just a means to the expansion, recreation, and growth of the "human." As such, its function is to perpetually inspire others to call new worlds into conceptual being.

It is Birkin's view of star friendship that makes such an aesthetic possible, an aesthetic that is based on the provisional instead of the absolute will. By acknowledging that his aesthetic creation is a falsity of his own make-up, Birkin tacitly invites others, like Ursula, to accept, reject, or redefine his art object. Were Ursula to fatalistically accept Birkin's Kunstwerk as a fixed conceptual reality, she would become like Mrs. Crich and Gudrun, mechanical beings who passively submit to others. Were Birkin to use an "assertive will" to cow others into submission, he would be like Loerke and Gerald, tyrannical beings who clearly exhibit "a sort of rottenness in the will" (117). ${ }^{16}$ Because Birkin, by contrast, uses a provisional "will" to construct life and his world, which he acknowledges as his own psychosemiotic construction imposed upon indefinable presence, he does not commit himself absolutely to his own conceptual system, nor does he demand that others accept it absolutely. Indeed, given modern psychology's culturally embedded psyche and Continental philosophy's evolving concept, Birkin considers art only that which inspires the endless creation of new worlds.

But for such an aesthetic experience to occur, "star-equilibrium" is necessary. The intense engagement between artist and audience, between friend and friend, makes possible the creation of new worlds. For Lawrence, until we abandon traditional philosophy's metaphysical mind and immutable concept, the life-giving, life-promoting relationship between artist and audience and between friend and friend will not be able to occur. But when we finally embrace psychology's culturally embedded psyche and Continental philosophy's evolving concept, we will, like Ursula, be able to experience ourselves as a work of art, a being with infinite potential to become: "In Ursula the sense of the unrealised world ahead triumphed over everything. In the midst of this profound darkness, there seemed to glow on her heart the effulgence of a paradise unknown and unrealised" (405). 


\section{Notes}

${ }^{1}$ James Joyce's "incertitude of the void" in Ulysses, William Butler Yeats's "The Circus Animals' Desertion," and Ludwig Wittgenstein's lost ladders of knowledge, Martin Heidegger's deconstruction of traditional metaphysics, and Kurt Goedel's analysis of grounding axioms as vulnerable - these are just a few of the major testaments that document the modernist crisis in knowledge. See Joyce (1986, 572), Yeats (1966), Wittgenstein (1988), Heidegger (1962), and Goedel (1962).

${ }^{2}$ For an excellent analysis of Clive Bell's attempt to establish an objective, metaphysical aesthetic, see Gould (1994). By distinguishing a "non-distinctive cause," in which emotions and subjective experience affect perception, from a "distinctive cause," in which a knowing faculty and a sensory apparatus determine perception, Gould argues that we can, according to Bell, have an objective perception of an art object's significant form.

${ }^{3}$ Ann Banfield does a first-rate analysis of the impulse for objectivity and universality in the early twentieth century. Specifically, she rightly claims that "Fry's aesthetic derives from analytic philosophy" $(2000,248)$, and as a consequence, she argues that for Fry art seeks the logical, fixed, and permanent patterns in the invisible reality behind the deceptive forms of appearance. Less compelling in this study is Banfield's attempt to use analytic philosophy to analyze Virginia Woolf's novels and aesthetic theories.

${ }^{4}$ Sanford Schwartz (1985) intelligently analyzes Hulme's aesthetic in terms of the opposition between conceptual abstraction and immediate experience. Specifically, Schwartz reads Hulme's work alongside Friedrich Nietzsche's and Henri Bergson's. My work differs in that I argue that Hulme and Nietzsche were poles apart in their thinking about language and the world. Nietzsche rejects the concept of reality, while Hulme seeks it; Nietzsche dismisses traditional religious concepts as irrelevant, while Hulme bases his aesthetic on original sin; and Nietzsche mocks belief in a prediscurisve Truth, whereas Hulme wishes to purify Philosophy so that we can access the "nature of reality."

${ }^{5}$ Eliot argues, contra G. K. Chesterton, that literature "should be unconsciously, rather than deliberately and definitely, Christian" $(1945,99)$. His task, therefore, would be to teach people to think through a Christian lens, even if they professed fidelity to a pagan creed, or no creed at all. Specifically, this means teaching people how to perceive the orthodox Truths of Christianity. For an analysis of Eliot's philosophy of an unconscious Christianity, see Lackey (2002).

${ }^{6}$ For excellent discussions of the Cambridge Apostles' philosophy and its extensive influence on Bloomsbury writers, see Rosenbaum (1987, 161-238) and Banfield (2000, 1-55).

${ }^{7}$ For a more extensive analysis of Woolf's radical critique of philosophy, see Lackey (2006b).

${ }^{8}$ Barry Allen (2003) sees Rudolf Carnap and Otto Neurath as the primary figures to formally distinguish Continental from analytic philosophy, while C. G. Prado makes a compelling case to consider "Gilbert Ryle's [1929] negative and dismissive review of Heidegger's Sein und Zeit as a somewhat arbitrary historical turning point" $(2003,9)$. While the split did not formally occur 
until the early 1930s, it is clear that many writers in the late nineteenth and early twentieth centuries were aware that a disciplinary crisis was imminent.

${ }^{9}$ Rorty uses this immutable/mutable distinction to distinguish analytic from conversational philosophy; see Rorty (2003). This distinction can be applied to the analytic/Continental split as well.

${ }^{10}$ For a more extensive analysis of the literary modernist understanding of and response to the pre-Continental/analytic crisis in philosophy, see Lackey (2006a).

${ }^{11}$ Mark Kinkead-Weekes (1996) and Tony Pinkney (1990) have taken note of Lawrence's antimodernist streak. For a useful discussion of Lawrence's complicated relationship to modernism, see Bell (2001).

${ }^{12}$ For useful discussions of the metaphysical assumptions of Western thought, see Rorty (1981; 1989).

${ }^{13}$ Fry specifically mentions Clive Bell's theories of "significant form" in his conclusion to Vision and Design (1947).

${ }^{14}$ In Thus Spoke Zarathustra, Zarathustra claims: “"This-is now my way: where is yours?' Thus I answered those who asked me 'the way.' For the way-does not exist!" $(1969,213)$. If Nietzsche believed in the ontological will to power, he would ask others to follow him, for it would only be through his philosophy that one could know "Being." But Nietzsche, like Birkin, is interested in the creation of "reality" rather than the discovery of Reality.

${ }^{15}$ In D. H. Lawrence: Language and Being, Bell does not distinguish between the absolute will, which Nietzsche rejects, and the provisional will, which he endorses, and as a consequence, he interprets the subject in Nietzsche as a site of impossibility: "Whereas Gerald is seen in explicitly Nietzschean terms, Birkin's concern for psychic wholeness and renewal makes him the more truly Nietzschean figure at all. The point could be put more subtly by saying that the two men represent between them the difficulty, perhaps the impossibility, of the Nietzschean self; an impossibility that that can indeed be deduced from Nietzsche's own writings" $(1992,105)$. According to my system, Gerald is not a Nietzschean figure; he represents the man of ressentiment, a figure that Nietzsche denounces as destructive and deadly. According to this interpretation, the Nietzschean self is not as impossible as Bell suggests.

${ }^{16}$ Lawrence probably got this particular view of friendship from Nietzsche, who claims: "Are you a slave? If so, you cannot be a friend. Are you a tyrant? If so, you cannot have friends" $(1969,83)$. 


\section{Works Cited}

Allen, Barry. 2003. “'Carnap's Contexts': Comte, Heidegger, Nietzsche.” In A House Divided:

Comparing Analytic and Continental Philosophy, 33-61. Amherst: Humanity Books.

Banfield, Ann. 2000. The Phantom Table: Woolf, Fry, Russell, and the Epistemology of

Modernism.Cambridge: Cambridge UP.

Bell, Clive. 1958. Art. New York: Capricorn Books.

Bell, Michael. 1992. D. H. Lawrence: Language and Being. Cambridge: Cambridge UP. . 1997. Literature, Modernism, and Myth: Belief and Responsibility in the Twentieth Century.

Cambridge: Cambridge UP. . 2001. "Lawrence and Modernism." In The Cambridge Companion to D. H. Lawrence, ed.

Anne Fernihough. Cambridge: Cambridge UP.

Chambers, Jessie.1965. D. H. Lawrence: A Personal Record. New York: Barnes \& Noble.

Eliot, T. S. 1934. After Strange Gods: A Primer of Modern Heresy. New York: Harcourt, Brace, \&

Company.

. 1945. "Religion and Literature." In Essays Ancient and Modern. London: Faber and Faber. . 1977a. Notes Towards the Definition of Culture. In Christianity and Culture. New York:

Harcourt Brace \& Company. . 1977b. The Idea of a Christian Society. In Christianity and Culture. New York: Harcourt

Brace \& Company.

Fry, Roger. 1947. Vision and Design. New York: Peter Smith.

Goedel, Kurt. 1962. On Formally Undecidable Propositions. New York: Basic Books.

Gould, Carol S. 1994. "Clive Bell on Aesthetic Experience and Aesthetic Truth." British Journal of Aesthetics 34(2):124-33.

Heidegger, Martin. 1962. Being and Time, trans. John Macquarrie and Edward Robinson. San Francisco: Harper \& Row.

Hulme, T. E. 1965. Speculations: Essays on Humanism and the Philosophy of Art, ed. Herbert Read. London: Routledge \& Kegan Paul.

Jay, Martin. 1996. "Modernism and the Specter of Psychologism.” Modernism/Modernity 3(2):93111.

Joyce, James. 1986. Ulysses. New York: Vintage Books.

Kinkead-Weekes, Mark. 1996. D. H. Lawrence: Triumph to Exile: 1912-1922. Cambridge:

Cambridge UP.

Lackey, Michael. 2002. "Virginia Woolf and T. S. Eliot: An Atheist's Commentary on the Epistemology of Belief," Woolf Studies Annual 8:63-90.

. 2006a. "The Literary Modernist Assault on Philosophy." Philosophy and Literature 30(1):50-60.

. 2006b. "Modernist Anti-Philosophicalism and Virginia Woolf's Critique of Philosophy." Journal of Modern Literature 29(4):76-98.

Lawrence, D. H. 1936. "Why the Novel Matters." In Phoenix: The Posthumous Papers of D. H. Lawrence, ed. Edward D. McDonald. New York: Viking Press. UP.

. 1984. The Letters of D. H. Lawrence. Ed. James T. Boulton, 3 vols. Cambridge: Cambridge

. 1988a. "Democracy." In Reflections on the Death of a Porcupine and Other Essays, ed.

Michael Herbert. Cambridge: Cambridge UP. . 1988b. "The Crown." In Reflections on the Death of a Porcupine and Other Essays, ed.

Michael Herbert. Cambridge: Cambridge UP. 
.2000. Women in Love. New York: Penguin Books.

Milton, Colin. 1987. Lawrence and Nietzsche: A Study in Influence. Aberdeen: Aberdeen UP.

Montgomery, Robert E. 1994. The Visionary D.H. Lawrence: Beyond Philosophy and Art.

Cambridge: Cambridge UP.

Nietzsche, Friedrich. 1968. The Will to Power, trans. Walter Kaufmann. New York: Vintage Books. . 1969. Thus Spoke Zarathustra, trans. R. J. Hollingdale. New York: Penguin Books. . 1989a. Twilight of the Idols, trans. R. J. Hollingdale. New York: Random House. . 1989b. On the Genealogy of Morals, trans. Walter Kaufmann and R. J. Hollingdale. New

York: Random House. . 1990. The Gay Science, trans. Walter Kaufmann. New York: Penguin.

Pinkney, Tony. 1990. D. H. Lawrence and Modernism. Iowa City: U of Iowa P.

Plato 1961. Ion. In The Collected Dialogues of Plato. Princeton: Princeton UP.

Prado, C. G. 2003. "Introduction." In A House Divided: Comparing Analytic and Continental

Philosophy, 9-16. Amherst: Humanity Books, 2003.

Ragussis, Michael. 1978. The Subterfuge of Art: Language and the Romantic Tradition. Baltimore: The Johns Hopkins UP.

Rorty, Richard. 1981. Philosophy and the Mirror of Nature. Princeton: Princeton UP. . 1989. Contingency, Irony, and Solidarity. Cambridge: Cambridge UP. .2003. "Analytic and Conversational Philosophy." In A House Divided: Comparing Analytic and Continental Philosophy, 17-31. Amherst: Humanity Books.

Rosenbaum, S. P. 1987. Victorian Bloomsbury: The Early Literary History of the Bloomsbury Group, vol. 1. New York: St. Martin's Press.

Ryan, Judith. 1991. The Vanishing Subject: Early Psychology and Literary Modernism. Chicago: U of Chicago P.

Schneider, Daniel J. 1986. The Consciousness of D. H. Lawrence: An Intellectual Biography. Kansas: UP of Kansas.

Schopenhauer, Arthur. 1969. The World as Will and Representation. Trans. and ed. E. F. J. Payne. New York: Dover.

Schwartz, Sanford. 1985. The Matrix of Modernism: Pound, Eliot, and Early Twentieth Century Thought. Princeton: Princeton UP.

Steinhauer, Harry. 1949. "Eros and Psyche: A Nietzschean Motif in Anglo-American Literature," Modern Language Notes 64:217-28.

Widmer, Kingsley. 1985. "Lawrence and the Nietzschean Matrix." In D. H. Lawrence and Tradition. Amherst: U of Massachusetts P.

Wittgenstein, Ludwig. 1988. Tractatus Logico-Philosophicus. Trans. C. K. Ogden. London and New York: Routledge \& Kegan Paul.

Woolf, Virginia. 1982. The Diary of Virginia Woolf, vol. 4. Ed. Anne Olivier Bell. San Diego:

Harcourt Brace \& Company. . 1984. "Modern Fiction." In The Common Reader: First Series. Orlando: Harcourt Brace \& Company.

Yeats, W. B. 1966. "The Circus Animals' Desertion." In The Variorum Edition of the Poems of $W$. B. Yeats, eds. Peter Allt and Russell K. Alspach. New York: Macmillan. 